\title{
New Feature for CMP: Noted Author's Question Period
}

\author{
Atwood D. Gaines ${ }^{1}$
}

(C) Springer Science+Business Media, LLC, part of Springer Nature 2018

As noted in the last issue of 2017, Culture, Medicine and Psychiatry, we launched a new feature, which was visible only to print copy subscribers (or editorial board members). This new feature is, The Noted Author's Question Period (NAQP). In our NAQP, an invited quest will accept questions from readers through the author's email address. She or he will then select the questions to answer. Questions may be submitted for 1 month following the appearance of this issue of CMP ((to the end of April). We do not expect that the NAQP will generate full-blown essays. Rather our Noted Authors may provide considered, and to the point, answers to the questions the Author feels are worthwhile. The number of questions the Author will answer will depend upon the author. Let the Questions begin!

The first Noted Author in the Question Period is Dr. Byron Good, Professor of Social Medicine at Harvard Medical School and Professor of Anthropology at Harvard University. Dr Good is author of many books and articles that are wellknown to the readers of CMP and is also this year's CMP Honorée.

Professor Good will receive questions at the following email address:

Byron_good@hms.harvard.edu

Atwood D. Gaines

atwood.gaines@case.edu

1 Case Western Reserve University, Cleveland, OH, USA 